\title{
Knowledge Management and Innovation:The Role of Virtual Social Networks in Innovative Consumer Behavior
}

\author{
André Grützmann', Fernanda Maria Felício Macedo²,André Luiz Zambalde
}

\begin{abstract}
Online social networks made up of actors with different degrees of innovativeness may allow knowledge management to collect new ideas and measure their acceptance. This research investigates consumer innovativeness and relationships with the uses and participation in social networks. This research has a quantitative exploratory scope, and among the main findings, we can mention that the dimensions of the adopted scale were corroborated by using factor analysis. The findings cannot be generalized, but there are evidences that relationship between social networking and innovative consumer behavior exists. Although there are limitations, correlations were found between the social dimension of innovativeness and information search in the networks and also the use of social networking information for the decision to purchase new products.
\end{abstract}

Keywords: online social networks; web-based innovation; innovation; knowledge management.

Departamento de Ciência da Computação, Universidade Federal de Lavras, Caixa Postal 3037, Lavras, MG, Brasil, $37.200-000$. 'Phone: +553538291944. E-mail: andre5@dcc.ufla.br. ${ }^{3}$ Phone: +55353829I534. E-mail: zamba@dcc.ufla.br ${ }^{2}$ Instituto de Ciências Sociais Aplicadas, Universidade Federal de Ouro Preto, Mariana, MG, Brasil, 35.420-000. Phone: +553I35574249. E-mail: profamacedo@yahoo.com.br 


\section{Introduction}

Innovation has been the focus of companies from diverse sectors due to a global increase in competition. The process of innovation, in part, is based on successful collection and exploration of new ideas from different sources. Nevertheless, the traditional process of research for innovation has shown increased cost and falling success rates. In this respect, cyberspace has been indicated as an environment rich in useful information, which is interesting for new product and service development processes.

According to Castells (2003), the advent of dissemination of Internet promoted a new social configuration which he calls network society, with a new economy influenced by information and communication technologies. Shorter product life cycles impose new complex challenges for companies. The Internet and the World Wide Web have been used as tools for collaboration, especially the virtual social networks. Granovetter (1973) shed light on the strength of the weak ties provided by social structures and their influence on innovation and the concept is being adapted to cyberspace.

The online environment, where the social networks proliferate, has become a privileged space for exchange of information and knowledge. That means attracting and maintaining different profiles of social actors online. Innovation and marketing management researchers are very interested in this scenario favorable to the spread of information from all types of sources.According toVon Huelsen (2008), social networks allow the consumer to assume different functions, from announcer or discloser even up to criticizer of a company.

Participation in these virtual communities leads people to present their ideas and perceptions regarding products and services, normally in the form of comments and opinions. It is this information, together with the personal characteristics and network user characteristics that may be established as strategic resources in the process of launching new products. For that to occur, the knowledge and innovation management sectors of companies should be able to incorporate this type of information. As the volume of comments and opinions generated daily on these networks is high, it becomes necessary to prioritize the acquisition of information focusing innovation.

The behavior motivated toward innovation is the focus of several studies, generating scales and other instruments for its prediction, as related in (Venkatraman and Price, 1990; Goldsmith and Hofacker, 199।; Baumgartner and Steenkamp, 1996). Considering the growing importance of the virtual environment, the present study investigated the existence of interfaces between consumer participation in virtual social networks and his/her propensity to adopt behavior favora- ble to innovation or acceptance of new products. In other words, the relationship between participation in social networks and innovative behavior of the consumer was investigated, having as a basis the interest in knowledge management with a focus on innovation.

This research proposal becomes relevant to the extent that, within the limits of the review of literature carried out, few articles were identified that relate the themes in question. Most of the research undertaken investigates marketing actions on social networks, as well as their impact on general behavior of the consumer or only on the motivations of the consumers in participating in social networks. The present investigation focuses on the innovative behavior of the consumer and use of social networks, with this being its main differential and source of academic contribution. The study collaborates in production of a new knowledge based on analysis of the related themes, aiming to provide subsidies for extracting knowledge in virtual environments.

In methodological terms, the scope of research is quantitative exploratory, with data being collected through the use of a structured questionnaire prepared from conciliation of the existing literature and the goals of this research. As the sample is non-probabilistic, the intention is not to generalize the results of this study, but reveal the relationship between virtual social networks and consumer innovative behavior in the given reality using statistical methods like factorial analysis and correlation. The results may provide a basis for future studies for the purpose of deepening this line of investigation.

\section{Knowledge and Innovation Management}

Organizations that wish to increase their market share have been enmeshed in various changes. Many of these changes are directly related to the ability companies manage to develop to effectively and efficiently use information. Indeed, it is necessary to do more than simply manage information. Considering the aspects related to knowledge, it is important that companies develop abilities to manage data, information and knowledge.

Knowledge management involves activities related to acquiring, using and sharing knowledge, both internally and externally. It demarcates methods and procedures for establishing links with companies, whether partners or competitors, customers or institutions. Finally, it involves aspects related to recognizing the value of knowledge.

For OECD (2005, p. 87), knowledge management involves the aforementioned activities on the part of the organization. It also involves outside connections, as well as flows that go beyond the company, and contemplates the search for and attainment of knowledge related to customers, sup- 
pliers and even competitors. The company must be able to establish rules for codification of knowledge, policies for its use and sharing of it.

Knowledge may allow the company to move ahead in the market and renew itself, but it may also make the company restrict itself to what it knows how to do well. While the latter perspective makes the company simply improve its products and services, the former perspective opens horizons toward innovation by means of exploration and the search for new things, new know-how. Choo and Bontis (2002) suggest that there should be a balance between preservation of existing knowledge and exploration of new knowledge.

Knowledge Management is being used in organizations that have intensive use of information and wish to enhance their abilities and qualifications. The use, exchange and obtaining of knowledge are fundamental for company operation. There should be suitable systems for managing knowledge and increasing both competitiveness and the ability to innovate. Web-based tools, among them web mining, facilitate interactions with customers and simplify absorption of knowledge at a relatively low cost when compared to traditional techniques (Prandelli,Verona and Raccagni, 2006).

\section{Innovative Behavior of the Consumer}

People's consumption habits have come under study with greater emphasis by the academic world with a view toward the need for aligning production and consumption. In times of intense competition, companies have sought out consumers to take part in product development, as indicated by some studies (Freeman, 1968; von Hippel, 1988; Shah, 2003). Of special importance are those known as lead users (Urban and von Hippel, 1988; Franke et al., 2006) because their opinion and behavior normally influence the other consumers.
Customers express their ideas, suggesting new characteristics or products or criticizing companies.

The study of this behavior is fundamental for companies, especially in the search for innovation. Innovation is of a multifaceted nature, being related to the predisposition to promote and/or accept change, whether it be radical or gradual (Schumpeter, 1985). Thus, for consumers to demand innovative products or ideas, they must be open to adopting a new type of habit as a result of acquisition of the innovation.

The innovative behavior of consumers has been researched by various authors (Midgley and Dowling, 1978; Hirschman, 1980; Foxall, 1988; Steenkamp, Hofstede and Wedel, 1999), although the concept of innovativeness is abstract and considered to be innate. Scales for measuring the aspects that delimit innovativeness are important, but not easily constructed.Vandecasteele and Geuens (20l0) sought to form a scale to consider different motivating factors for innovative behavior from the consumer, based on multiple dimensions (functional, hedonic, social and cognitive), briefly summarized in Table I.

Table I shows the dimensions that inspired construction of the instrument of the present study. As a result, it may be observed that various factors influence innovative behavior on the part of the consumer. Consumer motivation for innovation and participation in social networks are the focus of interest of this study. Below, some elements of virtual social networks are presented to complement the theoretical framework, so as to proceed to an outline of the study.

\section{Online Social Networks}

One of the precursors of studies on social networks is Granovetter (1973), together with Milgram (1967), Burt

\begin{tabular}{|l|l|l|l|}
\hline & Definition & Values & Example \\
\hline Functional & $\begin{array}{l}\text { Consumer motivated by functional } \\
\text { performance of the innovations, task } \\
\text { management and accomplishments. }\end{array}$ & Functional & $\begin{array}{l}\text { Usefulness, efficiency, } \\
\text { comfort, ease, quality, } \\
\text { reliability. }\end{array}$ \\
\hline Hedonic & $\begin{array}{l}\text { Consumer motivated by affective } \\
\text { stimulation from the innovation. }\end{array}$ & $\begin{array}{l}\text { Stimulation. Hedonism. } \\
\text { Emotional. }\end{array}$ & $\begin{array}{l}\text { Pleasure, emotion, de- } \\
\text { sire, getting out of the } \\
\text { routine. }\end{array}$ \\
\hline Social & $\begin{array}{l}\text { Consumer motivated by the need for } \\
\text { social self-affirmation for the differen- } \\
\text { tiation caused by innovation. }\end{array}$ & $\begin{array}{l}\text { Power (preserving pub- } \\
\text { lic image). Social Value. }\end{array}$ & $\begin{array}{l}\text { Prestige, distinction, } \\
\text { sense of belonging, } \\
\text { image. }\end{array}$ \\
\hline Cognitive & $\begin{array}{l}\text { Consumer motivated by the mental } \\
\text { stimulation from innovation. }\end{array}$ & $\begin{array}{l}\text { Knowledge. Skill, Intel- } \\
\text { ligence. }\end{array}$ & $\begin{array}{l}\text { Knowledge, intelligence, } \\
\text { learning, reasoning. }\end{array}$ \\
\hline
\end{tabular}

Table I.Aspects of the four dimensions of motivated consumer innovativeness.

Source: Prepared by the authors as based on Vandecasteele and Geuens (2010)

ISSN: 07 I8-2724. (http://www.jotmi.org)

Journal of Technology Management \& Innovation (c) Universidad Alberto Hurtado, Facultad de Economía y Negocios. 
(1992) and Wellman (1996). For the first author, personal experience of individuals is closely connected with large scale aspects of the social structure, and the macro-micro relationship is of central importance for sociological theory. According to Welmann (1996), a social network may be defined as a set of actors or nodes (people, companies or groups) and their connections, interactions or social ties. Granovetter (1973) affirmed that strong ties create local cohesiveness but lead to global fragmentation, while weak ties are indispensable for individual opportunity and integration with the community.

Recuero (2004) affirms that initial studies on networks focused on the structure but new perspectives came to be adopted in research on networks. Some models were created in an attempt to explain characteristics and properties of networks. The author lists them as: random networks models (the nodes should present a similar quantity of connections with the same chance of receiving new connections), small worlds model (the ties established between people closest to each other and some ties established between some nodes transformed the network into a small world) and unscaled networks models (the more connections a node has, the greater the chances of it having other connections).

Watts (2003) asserts that the focus on the structure or properties does not take into account the dynamic characteristic of network construction and maintenance, which are always evolving and undergoing modification through time. New technologies of communication, such as the world wide web, for example, constitute a new factor to be considered in the study of networks. The possibility of establishing contacts, overcoming the limitations of space, makes links between the members of networks more complex and dynamic, in the direction of the network society indicated by Castells (2003).

In the perspective of Lévy (1999), the role of information technology and information-based communication techniques is that of favoring construction of intelligent collective spaces where the social and cognitive potentialities of each one may be developed and expanded in a mutual way. Wellman (2005) complements that virtual relationships are filling empty spaces in the lives of persons, and not those spaces already filled by face-to-face activities.

Virtual relationships do not completely substitute face-toface interactions, acting in a complementary manner (Dimaggio et. al., 200I). These interactions in virtual networks, just as in face-to-face relationships, assist in creating social capital. Social capital favors internal and external cooperation of diverse social groups. This is not a property of a given individual, to the extent that it arises and depends on the interaction of at least two people, i.e., it consists of an asset of the network or group, which brings benefits to the collective body or creates restrictions for those who do not participate in it (Marteleto; Silva, 2004). Social capital is created in the structural ties of the network.

Granovetter (1973) shows that the establishment of strong ties reinforces the bonds of trust among members of the network; nevertheless, it only provides redundant information to it; in other words, there are the same sources of information. In contrast, the networks fed by weak ties present non-redundant information. The weak ties are bridges between diverse networks. The author affirms that the person that has a greater quantity of weak ties will more easily be able to learn of employment opportunities, for example, than people that only relate to their strong ties. Thus, participation in virtual networks can increase the possibility of establishing weak ties among individuals, substantially increasing the quantity of non-redundant information they may receive.

Based on this conception of social ties, Recuero (2009) proposes a classification of virtual social networks or of internet in two modalities, called the emergent network and the network through affiliation. Emergent networks may be defined as a set of connections among the nodes that arise by means of the social exchanges brought about by social interaction and conversation. The relationships arising from comments made on a weblog or photolog are an example. They are dynamic networks, continually constructed and reconstructed and, for the most part, are small. Such networks subsist based on the desire of the actors in creating friendships or sharing social support, trust and reciprocity in the attempt to establish stronger ties.

In contrast, networks through affiliation are formed when social actors join social network sites, like Facebook or Orkut.They are more stable and static than the emergent ones, not being altered by the increase or decrease of interactions and values exchanged. It is a broad scale network modality and it is not necessary to interact to maintain the connection, which is maintained by the system; that way, the ties may be weak.

We have to highlight that the points of differentiation between emergent networks and those through affiliation are subtle and the creation of strong ties may occur in a network through affiliation (Recuero, 2009). Thus, the fact is that, due to social capital and the relevance of the formation of strong and weak ties in a network, the position of the nodes or people in the network becomes quite strategic, i.e., the people in a better position may be opinion makers and, therefore, fundamental in dissemination of new ideas or products. 
According to Burt (2000), distinct structural positions lead to divergent actions in social relationships. The behavior of the nodes and of the group may be analyzed according to the unequal distribution of resources (information, wealth and influence), which depends on the position occupied in the social structure, through which individuals may provide or have access to such resources.

Consequently, we may conclude that participation in virtual social networks, both emergent and through affiliation, constitute an opportunity for formation of strong or weak ties between the nodes, with this structure favoring the circulation of information which may influence behavior of individuals as consumers. The origin of this information, if it comes from a node in a more relevant position in the network, may result in a more effective influence.

Based on this brief presentation on virtual social networks and how circulation of information is processed in its sphere, we proceed to presentation of the methodological aspects of the study.

\section{Methods}

The present study has a quantitative delineation since it aims at measurement of opinions, reactions, habits and attitudes in a sample of a given universe. The study also presents an exploratory configuration which is diagnostic in the initial phase, for later deepening of the research proposal, with a view toward the recent nature of the interrelations among the themes dealt with.

The sample used is characterized as non-probabilistic. The researcher decides which elements to include in the sample. This type of sample can offer good estimates of the characteristics of the population, but does not permit an objective assessment of the precision of the results from samples. For that reason, the estimates obtained are not statistically able to be projected over the population (Malhotra, 2006). Fonseca and Martins (1996) affirm that this sampling presupposes a deliberated choice of the elements of the sample, and it is not possible to generalize the results of research to the population as a whole because the non-probabilistic samples do not ensure the representative nature of the population. Non-probabilistic sampling is generally used in situations like the exploratory stages of a research project, pre-test of a questionnaire, handling a homogeneous population, when operational ease is required.

The population consists of 294 students of the undergraduate program in Management of a Brazilian federal university located in the state of Minas Gerais, with the sample made up of 127 students. The choice of undergraduate students in Management is due to their integration in an academic universe that encourages the formation of contacts and relationship networks, as well as easy access to the means of digital communication.

Volunteers answered a structured questionnaire with mostly closed questions for diagnosis of the profile of the sample. A nominal scale was also used for investigation of the use of Internet. Finally, the Likert scale was used to obtain the degree of agreement or disagreement with each one of a series of statements about networks and innovative behavior, based on a scale proposed by Vandecasteele and Geuens (20I0). The research instrument is available for consultation upon request to the corresponding author.

The Statistical Package for Social Sciences (SPSS v. 17.0) was used for data analysis given to its broad approval in the academic area. Various authors recommend this tool for statistical analyses from the most simplified up to other more complex ones (Maroco, 2007; Pestana, Gageiro, 2008; Hair Jr. et al., 2009).

Initially, we sought to outline the profile of the interviewees, considering socioeconomic aspects, possessions and use of computers and communication devices, as well as the usage rates of Internet and social networks. The intention was to confirm the characteristics of a young, university student and connected target group, which was effectively found.

Due to the recent nature of the consumer motivation scale for innovativeness that was used, we choose to carry out a factorial analysis with the twenty variables that constitute the scale. This step investigated whether the data adhered to the scale created by Vandecasteele and Geuens (2010) and whether the dimensions could be effectively used according to their original purpose, i.e., whether the factorial analysis of the data would return factors in keeping with the dimensions proposed by the scale. Thus, justification for use of the Likert scale taken on as a measure and the individual variables being grouped in sum totals for each dimension is reinforced.

After that, Spearman correlation analyses were used for the dimensions of innovativeness and interest variables were selected. The four dimensions (social, functional, hedonic and cognitive), social networks and uses of social networks served as a basis for the bivariate correlation tests with the aid of the SPSS software.

The data are presented in the next topic according to the criterion of parsimony, nevertheless seeking to leave the results of the statistically employed tests clear. Data analysis was carried out based on the theoretical framework, seeking understanding of consumer behavior, innovativeness and social networks. 


\section{Data Presentation and Analysis}

The sample of 127 respondents was composed of $56 \mathrm{fe}-$ males $(44.1 \%)$ and $7 \mathrm{I}$ males $(55.9 \%)$, with an average age of 22.2 years. The students interviewed entered the university mainly in $2010(57.3 \%)$ but there were also $34.6 \%$ entering in 2009 and $5.5 \%$ in 2008 . As could be expected in young university students, most (89.8\%) are single, with only $7.9 \%$ married and $2.4 \%$ in other situations.

In regard to employment and income, most (53.5\%) responded that they are not employed. Individual monthly income was concentrated in values of up to $R \$ 1500,00$. It is possible that this individual income is the fruit of financial assistance from parents or relatives since most were not employed. Responses to family monthly income were evenly distributed, with the $32.3 \%$ in the range above $R \$ 4590,0$ I standing out, and other with $25.2 \%$, between $R \$ 510,01$ and $R \$ 1530,00$. In addition to the other ranges, we notice that $1 \mathrm{I} .8 \%$ of those interviewed did not respond regarding family income.

The sample showed $75.6 \%$ of people who said they had a landline telephone and $96.9 \%$ have a cell phone. The main mobile line is of the pre-paid type, with $51.2 \%$ of the responses; however, the post-paid plans make up $48 \%$ of those interviewed, and there were non-respondents. Possession of a computer or notebook is indicated by $85 \%$ of the people. Only $11 \%$ said they had a smartphone for personal use and $76.4 \%$ have a credit card.

This data confirmed that it is a young group, with good purchasing power, even though dependent on the family. The degree of connectedness is also noteworthy, with a high percentage of computers and cell phones. This is consonant with the profile of university students, who may be a source of knowledge for innovation.
An expressive majority (82.7\%) affirms they use Internet every day, which is converted into a average of 14.55 hours weekly in the set of respondents, with 16.13 hours for those who use it daily and 6.21 hours for those who use it occasionally. Of those interviewed, $94.5 \%$ have used Internet for more than three years. The home is the most used location (74.8\%) for Internet access, followed by the university and work/internship with $9.4 \%$ each. The most common connection is broadband, with $85.8 \%$ of responses, and the portable computer is the most highly used piece of equipment for access, with $51.2 \%$, followed by a desktop computer, with $47.2 \%$ of those surveyed.

Table 2 shows the use of the virtual social networks, with a special emphasis on Orkut and instant messaging systems such as MSN and similar systems. We have to note that when the research was conducted, Facebook and Twitter was just starting in Brazil. The main networks are through affiliation (Orkut) and emergent ones (MSN/etc and others/ forums/blogs/etc.), indicating the presence of both weak ties (through filiation) and strong ties (emergent), according to Recuero (2009).

We investigated how the respondents used the Internet in the three previous months for the purpose of verifying the activities that stood out and if those interviewed really use the web resources. Internet is used for communication (email, instant messages) by $99.2 \%$ of the people. Leisure was indicated by $96.1 \%$, followed by education with $95.3 \%$ and reading at $92.1 \%$. In a lesser quantity, the use of Internet to search for information on internships or employment reached $72.4 \%$, purchases or orders of goods or services obtained $66.1 \%$, banking transactions, $33.9 \%$ and interaction with public authorities or government were cited by $29.9 \%$ of those interviewed.

\begin{tabular}{|l|l|}
\hline Virtual social network & Mentions \\
\hline Orkut & $83.5 \%$ \\
\hline MSN/etc & $78.7 \%$ \\
\hline Others/forums/blogs/etc & $24.4 \%$ \\
\hline Facebook & $19.7 \%$ \\
\hline Twitter & $18.1 \%$ \\
\hline MySpace & $3.9 \%$ \\
\hline Don't know or don't use & $3.1 \%$ \\
\hline Linkedln & $1.6 \%$ \\
\hline Hi5 & $1.6 \%$ \\
\hline Friendster & - \\
\hline
\end{tabular}

Table 2. Social networks used by those interviewed. Source: Research data

ISSN: 07I 8-2724. (http://www.jotmi.org)

Journal of Technology Management \& Innovation (c) Universidad Alberto Hurtado, Facultad de Economía y Negocios. 
The factorial analysis was undertaken due to the recent nature of the scale proposed by Vandecasteele and Geuens (2010), as well as the need for investigating the suitability of the twenty questions proposed in the research instrument, divided into four groups. Adherence of the data collected to this instrument allowed us to assume the scores of each one of the dimensions for the subsequent tests. Although the proportion is considered empirical, we obtained one hundred twenty-seven cases for twenty variables, going beyond the minimum ratio recommended for factorial analysis by some authors, including Hair Jr. et al. (2009).

The principal component analysis extraction method was used with Varimax rotation, Kaiser normalization and substitution of missing values with the mean. The Kaiser-MeyerOlkin (KMO) measure found was 0.812 and Bartlett's sphericity test showed a level of significance near zero $(0.000)$. Therefore, the factors explain the variability of the data well and the factorial analysis is adequate for this set. In addition, Cronbach's alpha coefficient reached 0.886 , above the 0.6 recommended by Nunnaly (1978).
The rotated component matrix, see Table 3, indicated four components, revealing total similarity with the innovativeness dimensions of the adopted scale. The social dimension groups the variables from 8 to 12 , in accordance with component I.The cognitive dimension establishes the set of variables from 23 to 27 , similar to component 2 . The identity between the hedonic dimension and component 3 is designated by variables 18 to 22 . Component 4 groups variables 13 to 17 , equaling the functional dimension.

With similarity between the factors shown by factorial anal$y$ sis and the dimensions of the adopted scale, the scores of the variables that compose the factors were added up, giving rise to the dimensions of Social Innovativeness, Functional Innovativeness, Hedonic Innovativeness and Cognitive Innovativeness, as well as Total Innovativeness (sum of the four dimensions), which were used in the correlation analyses. The numbering of the variables is related to their order in the questionnaire and also obeying the sequence used in the Vandecasteele and Geuens (2010) scale.

\begin{tabular}{|l|l|l|l|l|}
\hline & Component & & & \\
\hline Variable & $\mathrm{I}$ & 2 & 3 & 4 \\
\hline V8 & .718 & & & \\
\hline V9 & .832 & & & \\
\hline V10 & .780 & & & \\
\hline V11 & .826 & & & \\
\hline V12 & .735 & & & \\
\hline V13 & & & & .629 \\
\hline V14 & & & & .680 \\
\hline V15 & & & & .718 \\
\hline V16 & & & & .598 \\
\hline V17 & & & & .747 \\
\hline V18 & & & .602 & \\
\hline V19 & & & .780 & \\
\hline V20 & & & .677 & \\
\hline V21 & & & .809 & \\
\hline V22 & & & .589 & \\
\hline V23 & & .569 & & \\
\hline V24 & & .671 & & \\
\hline V25 & & .743 & & \\
\hline V26 & & .790 & & \\
\hline V27 & & .791 & & \\
\hline
\end{tabular}

Table 3. Rotated Component Matrix. Source: Research data Extraction Method: Principal Component Analysis. Rotation Method:Varimax with Kaiser normalization. Note: Rotation converged in 6 iterations.

ISSN: 07 I8-2724. (http://www.jotmi.org) 
Equitable division of those interviewed in regard to gender led us to investigate possible behavioral differences in regard to Internet usage time in hours (variable 5) and the dimensions of innovativeness (variables 8 to 27, divided up in the following manner: Social Dimension, v8 to v12; Functional Dimension, v13 to v17; Hedonic Dimension, v18 to v22; Cognitive Dimension, v22 to v27). Upon undertaking a comparison of the mean values by means of Analysis of Variance, within a level of significance of 0.05 , we did not find indications of difference among the mean values. That denotes that women are using the Internet just as much as men in our sample.

Total Innovativeness, calculated from the sum of the four dimensions of innovativeness established by Vandecasteele and Geuens (2010) and adopted in this study, was used to verify the Spearman's correlation with the different social networks used by the respondents. Table 4, in the hashed areas, indicates that Twitter and Facebook have positive correlation with Total Innovativeness, within the significance of 0.01 . Orkut shows correlation, however of lesser significance, at 0.05 , possibly due to the greater number of users. Facebook and Twitter had fewer users at the time of data collection and were recent in Brazil in 2010. Thus, it may be considered that the respondents that adopt these networks have slightly more innovative behavior than the others in this sample. Only the social networks presented in the Table 3 were used for correlation since the others showed a very small percentage in the sample.

Total Innovativeness broken down into Social, Functional, Hedonic and Cognitive Innovativeness was correlated with the same social networks. The data highlight the Spearman's correlation, see Table 5, between Social Innovativeness and Orkut and Twitter, and between Cognitive Innovativeness and Facebook. Functional Innovativeness and Facebook, Hedonic Innovativeness and Orkut and MSN/etc, and Cognitive Innovativeness and Twitter were lesser significant. Although Orkut did not appear in analysis of Total Innovativeness, the number of respondents exhibited a expected correlation with the Social dimension because it was one of the most used virtual social networks in Brazil. The other two correlations reinforce and complement the previous analysis, showing that users of Twitter and Facebook have greater innovative behavior, specifically in the social dimension for the former and in the cognitive dimension for the latter.

The data collection instrument used seven variables with the Likert scale to verify if those interviewed used the social networks for: v28 - search for information about new products; v29 - search for information about the brand; v30 - complain about products purchased which generate dissatisfaction; v3l - complain about companies that did not provide good customer service; $\mathrm{v} 32$ - use of information coming from social networks for the decision to purchase new products; $v 33$ - suggest new characteristics in existing products and v34 - suggest new products not yet on the market.

Table 6 shows that Total Innovativeness has Spearman's correlation with the search for information about new products, about the brand, as well as the suggestion for new products not yet on the market. Obviously, it is not possible to verify how these uses occur, even if only in the scope of our sample. However, it is noteworthy that the social networks are used by people with more innovative behavior, both for the search for information about products and companies and for the suggestion of new products.

The Spearman correlation of the dimensions of Innovativeness of the consumer (Social, Functional, Hedonic and Cognitive), with the variables about the use of social networks, showed some interesting and complementary aspects. Table 7 shows the Spearman's rho coefficients for the variables investigated. The hashed areas indicate correlations with significance at 0.01 .

It may be observed that functional innovativeness did not present correlation with any one of the variables of interest in this analysis. A more refined investigation regarding the motivations for the uses of social networks would be interesting to better understand these results. Apparently these networks are used by those interviewed as a source of information, learning or exhibitionism, not being considered when dealing with improvement in productive performance or task management.

\begin{tabular}{|l|l|l|l|l|l|l|}
\hline & & Orkut & Facebook & Twitter & MSN/etc & Others \\
\hline Total Innovativeness & Correlation coefficient & $.187^{*}$ & $.250^{* *}$ & $.305^{* *}$ & .050 & .006 \\
\hline & Signif. (two tailed) & .035 & .005 & .000 & .579 & $.95 \mathrm{I}$ \\
\hline & $\mathrm{N}$ & 127 & 127 & 127 & 126 & 127 \\
\hline
\end{tabular}

Table 4. Spearman Correlation between Total Innovativeness and Social Networks used. Source: Research data *Correlation is significant at the level of 0.05 (2-tailed). ** Correlation is significant at the level of 0.0I (2-tailed).

ISSN: 07I 8-2724. (http://www.jotmi.org)

Journal of Technology Management \& Innovation (c) Universidad Alberto Hurtado, Facultad de Economía y Negocios. 


\begin{tabular}{|l|l|l|l|l|l|l|}
\hline & & Orkut & MSN/etc & Others & Facebook & Twitter \\
\hline Social Innovativeness & Correlation coefficient & $.239^{* *}$ & .173 & -.018 & .127 & $.255^{* *}$ \\
\hline & Signif. (two tailed) & .007 & .053 & .844 & .155 & .004 \\
\hline & $\mathrm{N}$ & 127 & 126 & 127 & 127 & 127 \\
\hline Functional Innovativeness & Correlation coefficient & -.011 & -.073 & .006 & $.209^{*}$ & .171 \\
& & & & & & \\
\hline & Signif. (two tailed) & .899 & .413 & .946 & .018 & .055 \\
\hline & $\mathrm{N}$ & 127 & 126 & 127 & 127 & 127 \\
\hline Hedonic Innovativeness & Correlation coefficient & $.21 \mathrm{I}^{*}$ & $.200^{*}$ & .137 & .073 & $.207^{*}$ \\
& & & & & & \\
\hline & Signif. (two tailed) & .017 & .025 & .124 & .418 & .019 \\
\hline & $\mathrm{N}$ & 127 & 126 & 127 & 127 & 127 \\
\hline Cognitive Innovativeness & Correlation coefficient & .125 & -.108 & -.024 & $.234^{* *}$ & $.226^{*}$ \\
& & & & & & \\
\hline & Signif. (two tailed) & .162 & .227 & .792 & .008 & .011 \\
\hline & $\mathrm{N}$ & 127 & 126 & 127 & 127 & 127 \\
\hline
\end{tabular}

Table 5. Spearman Correlation between dimensions of Innovativeness and Social Networks used. Source: Research data

* Correlation is significant at the level of 0.05 (two tailed). ** Correlation is significant at the level of 0.01 (two tailed).

\begin{tabular}{|l|l|l|l|l|l|l|l|l|}
\hline & & $\mathrm{v} 28$ & $\mathrm{v} 29$ & $\mathrm{v} 30$ & $\mathrm{v} 31$ & $\mathrm{v} 32$ & $\mathrm{v} 33$ & $\mathrm{v} 34$ \\
\hline Total Innovativeness & Correlation coefficient & $.328^{* *}$ & $.237^{* *}$ & $.210^{*}$ & $.205^{*}$ & $.178^{*}$ & $.218^{*}$ & $.264^{* *}$ \\
\hline & Signif. (two tailed) & .000 & .007 & .018 & .022 & .046 & .014 & .003 \\
\hline & $\mathrm{N}$ & 127 & 127 & 126 & 126 & 126 & 127 & 127 \\
\hline
\end{tabular}

Table 6. Spearman Correlation between Total Innovativeness and uses of social networks. Source: Research data

* Correlation is significant at the level of 0.05 (two tailed). ** Correlation is significant at the level of 0.01 (two tailed).

\begin{tabular}{|l|l|l|l|l|l|l|l|l|}
\hline & & $\mathrm{v} 28$ & $\mathrm{v} 29$ & $\mathrm{v} 30$ & $\mathrm{v} 31$ & $\mathrm{v} 32$ & $\mathrm{v} 33$ & $\mathrm{v} 34$ \\
\hline Social Innovativeness & Correlation coefficient & $.304^{* *}$ & $.312^{* *}$ & $.218^{*}$ & $.273^{* *}$ & .159 & $.199^{*}$ & $.265^{* *}$ \\
\hline & Signif. (two tailed) & .001 & .000 & .014 & .002 & .075 & .025 & .003 \\
\hline & $\mathrm{N}$ & $\mathrm{I} 27$ & $\mathrm{I} 27$ & 126 & 126 & 126 & $\mathrm{I} 27$ & 127 \\
\hline & Correlation coefficient & .108 & .055 & .099 & .095 & .079 & .107 & .067 \\
\hline & & & & & & & & \\
\hline & Signif. (two tailed) & .229 & .537 & .268 & .290 & .377 & .232 & .451 \\
\hline & $\mathrm{N}$ & 127 & 127 & 126 & 126 & 126 & 127 & 127 \\
\hline Hedonic Innovativeness & Correlation coefficient & $.401^{* *}$ & $.253^{* *}$ & $.226^{*}$ & .167 & $.329^{* *}$ & .142 & $.202^{*}$ \\
\hline & & & & & & & & \\
\hline & Signif. (two tailed) & .000 & .004 & .011 & .062 & .000 & .111 & .023 \\
\hline & $\mathrm{N}$ & 127 & 127 & 126 & 126 & 126 & 127 & 127 \\
\hline Cognitive Innovativeness & Correlation coefficient & .116 & .127 & .084 & .059 & .127 & $.277^{* *}$ & $.310^{* *}$ \\
\hline & Signif. (two tailed) & .196 & .156 & .347 & .513 & .156 & .002 & .000 \\
\hline & $\mathrm{N}$ & 127 & 127 & 126 & 126 & 126 & 127 & 127 \\
\hline
\end{tabular}

Table 7. Spearman Correlation between dimensions of innovativeness and use of social networks. Source: Research data

* Correlation is significant at the level of 0.05 (two tailed). ** Correlation is significant at the level of 0.01 (two tailed).

ISSN: 07 I8-2724. (http://www.jotmi.org)

Journal of Technology Management \& Innovation (c) Universidad Alberto Hurtado, Facultad de Economía y Negocios. 
Social innovativeness showed a positive correlation with variables v28 (0.04), v29 (0.3 I 2), v3। (0.273) and v34 (0.265). This may represent that the search for information, both about products and about companies, complaints about companies and the suggestion of new products not yet on the market are more important for the people that seek innovation motivated by the social aspect. The greater quantity of correlations between Social Innovativeness and variables regarding the use of social networks, in a certain way, corroborates the use of these networks for innovation, even though in their initial stages.

It is intriguing to note that innovativeness with hedonic motivation shows positive correlation with the search for information (v28 and v29) and also with the use of information from social networks for the decision to purchase new products (v32). Apparently, this correlation with variable 32 would be expected for innovation motivated by the social aspect.

The cognitive motivation for innovativeness of the consumer showed positive correlation with the variables regarding the use of social networks to suggest both new characteristics in existing products and to suggest new products. The expectation was for correlation also with variables 28 and 29 , regarding the search for information, which ended up not being shown by the tests.

Analyses of tables 6 and 7 show that variables v28, v29 and v34, with greater correlation with Total Innovativeness, may be broken down into two dimensions. While for the search for information both about products and brands we have correlation with social and hedonic innovativeness, the suggestion of new products is correlated with the social and cognitive dimensions. We must note that the social dimension shows the need for social approval and the hedonic dimension highlights the consumer motivated by positive reinforcement and sensorial gratification. For its part, the cognitive dimension is related to intellectual stimulation.

\section{Conclusion}

The evolution of society and its reflection on the economy has made companies that work in an isolated manner no longer capable of fulfilling the needs of their customers. On the one hand, products are ever more complex and require investments to create them; on the other hand, product life cycles are shorter and therefore opportunities for return on investment are reduced. In addition, increased competition presents new challenges and demands that corporations act innovatively to remain in the market.Social networks have been transformed into a focus of interest for diverse companies because the content generated in them comes from consumers with a wide range of interesting profiles. Besides the messages related to friendship and professional aspects, it is common to find reviews and analyses regarding products and services. It is precisely this content that organizations wish to collect, process and analyze to assist them in their business dealings. The quantity of information on the web has grown significantly in the past decade and it is a universe to be researched to find opportunities for innovation. Innovation-oriented knowledge management must ascertain if this information is significant and useful.

Therefore, the use of tools and techniques that make such activities viable is desirable in the routine of organizations. In the case of innovation, it is of fundamental importance if the sources are the consumers themselves. The organization benefits from the learning of the users of its products and retains knowledge. Participation in the network allows the members of the virtual communities to discuss new ideas which are available to all, leading to a possible increase in competitiveness.

The present article identified within the sample surveyed that the virtual social networks may be used for sharing of information, which has already been indicated by other studies. It means that knowledge management may be used to capture the information made available on these networks because they can contain criticisms of products or brands or other aspects considered important for consumers. Occasionally, these same consumers may suggest new products, that is, ideas for potential innovations.

The correlations found in our sample show the existence of consumers willing to share information on the virtual social networks, part of them having innovative behavior. These people have the potential to not only serve as sources of ideas but they may act as disclosers of new products and services.

As long as we used a non-probabilistic sampling the results cannot be projected to the population. Nevertheless, the evidence found suggests the need for new studies deepening the theme and using different research methods. The virtual social networks are a growing phenomenon and the content produced by consumers with innovative behavior is especially important for management of knowledge directed toward innovation.

The strategies for use of the web and its tools for advertisement must consider both the managerial and the academic focus. For that reason, new research for understanding the web environment and online behavior in virtual social networks need to be developed. We suggest that upcoming studies focus on analysis of interactions of innovative consumers with specific companies, seeking to identify if the content generated on the web can be used in the internal processes of innovation-oriented knowledge management. 


\section{Acknowledgements}

The authors would like to thank FAPEMIG for the partial financial support to this research and the Graduate Program in Management of the Federal University of Lavras (UFLA).

\section{References}

BAUMGARTNER, H., Steenkamp, J.-B. E. M. (1996). Exploratory consumer buying behavior: Conceptualization and measurement. International Journal of Research in Marketing, I3(2), $|2|-\mid 37$.

BURT, R. S. (1992). The social structure of competition. In: Nohria, N., Eccles, R. G. Networks and Organizations: structure, form and action. Boston: Harvard Business School Press.

BURT, R. S. (2000). The network structure Of Social Capital. In: Sutton, Robert I., Staw, B. M. (Ed.). Research in organizational behavior. Greenwich: Jai Press.

CASTELLS, M. (2003). A Sociedade em Rede. São Paulo: Paz e Terra.

CHOO, C.W., Bontis, N. (2002). The Strategic Management of Intellectual Capital and Organizational Knowledge. New York: Oxford University Press.

DIMAGGIO, P. et al. (200I). Social implications of the Internet. Annual Reviews Sociology, 27, 307-336, Aug 200 I.

FONSECA, J. S., Martins, G. A. (1996). Curso de Estatística. São Paulo.

FOXALL, G. R. (1988). Consumer innovativeness: Noveltyseeking, creativity and cognitive style. Research in Consumer Behavior, 3, 79-II3.

FRANKE, N., von Hippel, E., Schreier, M. (2006). Finding commercially attractive user innovations: An exploration and test of lead user theory. Journal of Product Innovation Management, 23(4), 30I-3I5.

FREEMAN, C. (1968). Chemical process plant: innovation and the world market. National Institute Economic Review, 45, 29-57.

GOLDSMITH, R. E., Hofacker, C. F. (I99I). Measuring consumer innovativeness. Journal of the Academy of Marketing Science, 19(3), 209-221.

GRANOVETTER, Mark. (1973). The strength of weak ties. American Journal of Sociology, 78(6), I360-I380.
HAIR Jr., J. F. et al. (2009).Análise multivariada de dados. 6. ed. Porto Alegre: Bookman.

HIRSCHMAN, E. C. (1980). Innovativeness, novelty seeking, and consumer creativity. Journal of Consumer Research, 7(3), 283-295.

LÉVY, P. (1999).A inteligência coletiva: por uma antropologia do ciberespaço. São Paulo: Loyola.

MALHOTRA, N. K. (2006). Pesquisa de marketing: uma orientação aplicada. Porto Alegre: Bookman.

MAROCO, J. (Ed.). (2007). Análise estatística: com utilização do SPSS. 3. ed. rev. ampl. Lisboa: Edições Sílabo.

MARTELETO, R. M., Silva, A. B. O. (2004). Redes e capital social: o enfoque da informação para o desenvolvimento local. Ciência da Informação, Brasília, 33(3), 4l-49.

MIDGLEY, D. F., Dowling, G. R. (1978). Innovativeness: Concept and its measurement. Journal of Consumer Research, 4(4), 229-242.

MILGRAM, S. (1967).The small world problem. Psychology Today, I, 6I-67.

NUNNALY, J. (1978). Psychometric theory. New York: McGraw-Hill.

OECD/European Communities. (2005). Oslo Manual: Guidelines for Collecting and Interpreting Innovation Data. 3. ed. Paris: OECD Publishing. Available at: <http://browse.oecdbookshop.org/oecd/pdfs/browseit/9205 I I I E.PDF>.[Accessed Aug, 20I0].

PESTANA, M. H., Gageiro, J. N. (2008). Análise de dados para ciências sociais: complementaridade do SPSS. 5. ed. rev. e corr. Lisboa: Edições Sílabo.

PRANDELLI, E., Verona, G., Raccagni, D. (2006). Diffusion of Web-Based Product Innovation. California Management Review, 48(4), I09-I 35.

RECUERO, R. (2004). Redes Sociais na Internet: considerações iniciais. In: XXVII Intercom, 27,2004, Porto Alegre.

RECUERO, R. (2009). Redes Sociais na Internet. Porto Alegre: Sulina.

SCHUMPETER, J. A. (1985). Teoria do desenvolvimento econômico. São Paulo: Nova Cultural. 
SHAH, S.K. (2003). Community-Based Innovation \& Product Development: Findings From Open Source Software and Consumer Sporting Goods. Ph.D. thesis, Sloan School of Management, Massachusetts Institute of Technology: Cambridge.

STEENKAMP, J.B. E. M., Hofstede, F., Wedel, M. (1999). A cross-national investigation into the individual and national cultural antecedents of consumer innovativeness. Journal of Marketing, 63(2), 55-69.

URBAN, G. L., von Hippel, E. (1988). Lead user analyses for the development of new industrial products. Management Science, 34(5), 569-582.

VANDECASTEELE, B., Geuens, M. (2010). Motivated Consumer Innovativeness: Concept, measurement, and validation. International Journal of Research in Marketing, 27, 308318.

VENKATRAMAN, M. P., Price, L. L. (1990). Differentiating between cognitive and sensory innovativeness: Concepts, measurement, and implications. Journal of Business Research, 20(4), 293-315.

VON HIPPEL, E. (1988). The Sources of Innovation. Oxford: Oxford University Press.

VON HUELSEN, P. (2008). Redes sociais na internet: as comunidades e os blogs como oportunidades para a publicidade e o marketing. São Paulo. Dissertação (Mestrado) Puc.

WATTS, D. J. (2003). Six Degrees: The Science of a Connected Age. New York:W.W. Norton \& Company.

WELLMAN, B. (1996). Are personal communities local? A dumptarian reconsideration. Social Networks, 18(4), 347354.

WELLMAN, B. (2005). Community: From Neighborhood to Network. Communications of the ACM, 48(I0), 53-55. 